University upon the value of the different kinds of stones best adapted to road building.

In Massachusetts, the towns are taking up the sub. ject and the dissemination of the good work in this important branch of internal improvements is thus permeating the entire State. This work is not limited to Massachusetts, since a number of the States have already passed new road laws, and the subject is being popularly discussed throughout the entire country. Especially in urban life is the sanitation of the street of the greatest importance, and it seems to me most fitting that the scientific men of the country should exercise a molding influence upon the development of this great public improvement. I have therefore deemed it fitting to ask the attention of the members of the Section in State Medicine of the American Medical Association to this subject and to give it due discussion and deliberation.

The subjoined letters are of interest and value. They represent purposely, several of our larger cities in widely varying latitudes with marked variations of climate:

Chief Sanitary Inspector's Office, Atednta, (4A., July $23,1894$.

HeNRY O. MARCY, M.D.-Deur Sir:-Your letter of July 20 to hand, and in reply will state that I consider the "asphalt paving" the prettiest paving for your avenues in Boston; it is easily kept clean, is noiseless, and would give entire satisfaction. Any further information I will gladly furnish.

Very respectfully, 'THos. E. VeaL, Chief Inspector.

City Surveyor's OfFice.

Moxtreal, Can. July 23, 1894.

Henty O.MaRCy, M.D.-Dear Sir:-I am in receipt of your letter of July 20, asking me for my opinion as to the best pavement to be used for a residental street with light traffic thereon. I would certainly recommend Trinidad asphalt. We have had Trinidad asphalt laid by the Warren Scharff Co., of New York, and it has stood this climate for seven years with heavy traffic. Yours truly,

P. IV. St. Georize, City Survejor.

Office of City Exgineer,

Savaniah, Ga., July $23,1894$.

Henry O. Marcy, M.D.-Dear Sir:-Your note of July 20 came to band and contents noted. The city of Savannah has a great many streets paved with asphalt, and it gives entire satisfaction. The Warren Scharff Paving Co. has done most of our work. It stands heavy traffic as well as light. I am yours respectfully,

Johs FitzGerald, Sup't Streets.

Department of Public Works, ChICAGo, July 23,1894

Henry O. Marcy, M.D.-Dear Sir:-Your favor of July 20 , relative to asphalt pavement received. We have 16.65 miles of sheet asphalt streets in this city. This class of improvement when well laid has given general satisfaction on resident streets in this city. Dearborn Avenue, which was improved with asphalt eleven years ago, bas just been repaired at an expense to the city of $\$ 570$. It is now in as perfect condition as it was when originally completed. Yours very truly,

JohN MCCaRTHY, Superintendent of Streets.

Departient of Public Works, Commissioner's Office, No. 31 Chambers Street, New York, July 24, 1894.

Henry O. Marcy, M.D.-Dear Sir:-In answer to your inquiry of July 20, regarding experience in this city with asphalt pavements, I beg to say that the experience of the last six years has shown good asphalt to be the very best pavement for residental streets and on streets used for pleasure driving, provided the grades are not too steep; that is, not to exceed 4 in 100 . It has many advantages over macadam or stone, in being noiseless, impervious to liquid filth, easy to keep clean, and about one-fourth less expensive to maintain. We have now in this city fifty-five miles of asphalt pavement, nearly all in private residental and tenement-house districts. Very respectfully,

Michael T. DaLy,

Commissioner of Public Works.
Street Departinent, Street Comuissioner's OfFice, St. Louis, Mo., July $24,1894$.

Henry O. Marcy, M.D.-Dear Sir:-Answering your favor of July 20 , would say that we have a little over nine miles of asphaltum streets in St. Louis, and they are giving entire satisfaction to the tax-payers. We have not confined the use of asphaltum streets to light trafic alone, as we have roadways here paved with that material over which from 5,000 to 7,000 vehicles pass daily with loads of from 1,000 to 10,000 pounds. Personally and officially $I \mathrm{am}$ in favor of asphalt for paving all classes of streets.

Very respectfully,

Y. J. MURPHY, Street Commissioner.

\section{PHYSICAL EDUCATION IN CHILDHOOD AND YOUTH A MEANS OF PREVENTING DISEASE.}

Read in the Section on State Medicine, at the Forty-sixth Annual Ieeting of the American Nedical Associution, at Baltimore, Md., May $7-10,1895$.

BY C. F. ULRICH, A.M., M.D. WHEELING, W. VA.

The time is rapidly approaching when the prevention of disease will be regarded as of infinitely more importance than its cure. The medical profession, al though not absolutely pure, is parexcellence, a benevolent and unselfish body. Where will you find a set of men who do so much for the general welfare, although their efforts tend continually to diminish their own profits and curtail their own income, as the medical brotherhood? Herculean labors have been performed by the fraternity to improve the water supply of our cities for the purpose of preventing disease and diminishing the death rate. Jenner's discovery, aided by a highly improved system of quarantine, has so diminished the ravages of variola. that it is no longer a terror to any community, and its approach is not dreaded as in times past. Cholera. has not the same terrors for us now that it had in days of yore. Although Professor Koch's discovery of tuberculin was prematurely launched into the world and has consequently disappointed the expectations of its friends, it is only a question of time, and not a very long time, until this discovery is supplemented by others that will enable us to come as near stamping out that fatal scourge as we have the smallpox. Diphtheria has hitherto baffled our efforts, and continued to slay its thousands. But the discovery of antitoxin bids fair to remand that much dreaded disease to the list of those which we have under our cuntrol. The unselfish physician is persevering in his unfaltering efforts to prevent disease; or at least to soften its asperity and shorten its duration; notwithstanding this work seems to go directly against his private interest, in removing to a great extent the source of his income.

There is, however, one prolific source of disease, or at least tendency to disease, of which I have heard very little mention made in medical societies, nor have $I$ read anything about it in medical journals. I refer to the neglect of physical training in childhood and youth. In the earlier ages of the world, when war and the chase formed the principal occupations of the human race, there was not so much need of admonition on this subject. The male child, in its tenderest yeare, was taken in hand and instructed in running, leaping, hurling the javelin and bending the bow, to prepare it for the life it was destined to lead when it reached the period of manhood. The barbaric tribes knew the necessity of health and strength in the mother to enable her to bear healthy 
children. They accordingly trained their female in- always tired. They are pale and thin; their flesh is fants in the exercises that were necessary to prepare flabby; the heart beats feebly; the brain is always them for the duties devolving upon them in woman- in a state of excitement, and frequently a hectic hood. In our modern exotic civilization, the idea of f flush is seen on their cheeks.

the necessity for such early training seems to have been lost sight of. Intellectual culture, moneymaking and general business habits seem to occupy the entire attention of our people at the present time.

A child inheriting a weak constitution from its parents, whose physical development has been neglected by parents who devoted themselves exclusively to intellectual or financial pursuits, or to fashionable follies, is sent to school to be crammed with evanescent knowledge, instead of having its physical organization developed and trained to endure the hardships of life, and its intellectual faculties drawn out to enable it to think for itself and acquire the necessary education after its school days are over. This child is required to sit at the school desk from four to six hours every day, trying to absorb knowledge, perhaps to be forgotten in a few months after leaving school. There is not even any supervision exercised over the position of the child's body, and frequently the naturally weak child comes out of school with stooped shoulders or lateral curvature of the spine. The general circulation not being promoted by juadicious and methodical training, the child is pale and flabby, drags itself along like an invalid of long standing, loses even its ambition to excel in the intellectual pursuits that first inspired it, and sometimes becomes a burden to itself and its friends.

If the child is of an active disposition, fond of physical exercise, it will sit during school hours fidgeting about, anxious for the recess or intermission to be announced. Then it will rush out, leap, run and bound like some wild animal escaped from the cage, perhaps doing itself an injury. There will be no system about the exercise, some organs being worked too much and others not enough. The body will be overheated and the muscles tired out. The body is not refreshed and the mind not rested. The blood that has been overheated will cool off too rapidly and a revulsion will set in. The muscles that have been overworked will be tired out and sore, being relaxed and unfit for duty the next day. The heart, that great machine that keeps the body alive, as well as the mind, by supplying the necessary nutriment, being overexcited, gradually loses its strength, becomes flabby; dilatations and valvular insufficiency are established. The buoyant health and strength that this child started with, which was perhaps the only heritage it received, is lost by mismanagement; the foundations of life sapped, and its future prospects destroyed.

Take, now, another class; those who, although not robust but rather of a delicate physique, are not suffering from any constitutional debility. We will suppose these children to be of a studious nature, possessing a large and active brain, with no particular desire for physical exercise. Such children go to school, sit in their confined seats, devoted to their studies. When recess is called they feel a bodily languor that makes them feel indisposed to move about and exercise their limbs. They prefer to remain in the schoolroom and study their lessons. When school is dismissed they drag themselves languidly along the street to their homes. They do not engage in the sports of their companions for they are

Let us now look at the child that has been systematically trained in all those physical exercises that develop the muscles without breaking them down; that strengthen and regulate the nerves without unduly exciting them; that cause a regular and healthy circulation of the blood without overheating it or allowing it to stagnate. If such a child has inherited a good constitution this course of training will still further improve it. The child of weak constitution, by such a course, will be strengthened and improved until its cachectic condition has almost disappeared; although, of course, it is not as robust as the one that began life with an inheritance of good health.

Now let us compare two children that are stricken down by disease; one whose physical training has been neglected, whose condition is as I have described above, and one whose physical forces have been well developed by a judicious course of training. Let us suppose that pneumonia is the disease that has attacked these two children. Which one will have the better prospect for recovery? The strong child has, by skillful training, developed all its organs, especially the lungs, which, by continual exercise under the supervision of a competent instructor, have been well developed and are consequently able to throw off the products of the disease, or even resist the attacks altogether, while the child whose physical education has been entirely neglected, who has been allowed to sit bent up in the schoolroom, having little or no play of the lungs; either not going out on the playground at all, or endeavoring to play with the stronger, more robust and more active children, overdoing itself and leaving its lungs in a worse condition than before, has to succumb to the terrible disease.

Take a case of typhoid fever and see how the two will fare. In this, as in other fevers, the heart has to double, treble, or even quadruple the work that is required of it in health. Now which heart will be able to accomplish it without coming to grief? You all know it will be the heart of the strong child, the one that has enjoyed good physical training and has been strengthened by a judicious and well regulated course of exercise; while the weak and flabby heart, with its imperfect valves, its thin walls, its dilated ventricles, which is scarcely able to perform its work when no disease is present, is sure to fail when double even quadruple the labor is required of it. In typhoid fever we have a diseased condition of the intestines near the ileocecal valve. Frequently, the coats of the intestines in this region are very much thinned. During the period of convalescence, when the patient begins to eat, owing to the slow digestion gases accumulate in the bowels, rupture of the intestinal coats takes place and death ensues. In which patient is this more likely to occur? In the one whose organs and tissues, owing to a good physical development, are all in a sound and healthy condition, able to endure a strain, to throw off the products of the disease, to resist the encroachment of the destroying malady; or in the one who is weak, the muscular coat of whose intestines has lost its peristaltic power, rendering it unable to carry off the products of the disease. which are thus permitted to remain stationary, preying still 
farther on the tissues until they become thin, unelastic and friable.

Consider another class of diseases, a product of our modern civilization, of which the ancients knew nothing; nervous affections. I presume no one will hesitate to decide which class is most liable to these affections. The man or woman who has been properly trained, the intellectual and physical powers having been developed pari passu, whose organıation is well balanced; the brain with its dependencies; the nervous system; the muscular system, with its locomotive powers; the alimentary tract; the assimilative apparatus, as well as all the emunctories, in good condition as a result of a sensible course of physical training in childhood and youth, will surely be less aff'ected by nervous disorders and their concomitant pain and misery than the pale, weak, flabby being that is in every respect the reverse of the one $I$ have just described.

It is hardly necessary to say anything as to the causes that render such persons amenable to all kinds of nervous diseases, for I am sure every one of you can see it at a glance. When one of these nervous, excitable creatures is attacked by fever, no matter what may be its character, it is easy to foresee the result. There is no power of resistance and the patient must succumb. Should this person, nevertheless, survive the attack, he or she would remain a wreck and life would be a burden. It is unnecessary to multiply instances as the matter is self-evident, and every physician, yes, every intelligent layman will see it as soon as it is suggested to him.

I remember when $I$ was a boy, the men in my native land, Germany, were not very robust, because they devoled themselves to intellectual pursuits without giving proper care to the condition of their bodily functions and powers. About forty-five or fifty years ago, Father Jahn, as he was popularly called, organized gymnastic societies, known as the Turnerbund. The young men, with great enthusiasm, affiliated with this association. Teachers were appointed; regular systematic instructions were imparted and the youth of the period became more and more athletic. When Prussia assumed the lead in the German confederation, thorough military drill was superadded to the gymnastic training, and the German people became a nation of athletes, recovering the reputation for strength and size of limb they enjoyed in the days of Tacitus, the ancient Roman historian. When; after an absence of half a century, I revisited my native land I was astonished to find so large a proportion of the population large, strong and athletic. Nor had they suffered in intellect by this physical growth, as was very plainly shown by their artistic, scientific, literary and educational display at the World's Fair in 1893.

Having now shown, I hope, to your satisfaction, the importance, yes, the absolute necessity of early physical training, and its remarkable influence on the health of, not only the present, but also future generations, and its great bearing on the physical and intellectual welfare of the human race, I will close these remarks by expressing the hope that our sanitarians will take the subject into consideration and see if something can not be done to promote a wise system of physical training, in connection with our intellectual education, which would certainly be an excellent safeguard against deterioration, both physical and intellectual, and would surely do more to advance our people to the highest degree of culture than the present system of cramming the brain with evanescent knowledge, and allowing the physical powers to dwindle away, a prey to the ravages of disease and death. According to the laws of heredity and the survival of the fittest, the time would not be very far distant when the earth would be peopled with a healthy, strong and intellectual race, among whom sickness, suffering and premature death would be the exception and not the rule.

\section{THE HYGIENIC AND SCIENTIFIC VALUE OF EXAMINATIONS OF THE EYES AND}

\section{EARS OF SCHOOL CHILDREN.}

Read in the Section on State Medicine at the Forty-sixth Anuual Iteting of the American May $7-10.1895$.

BY B. AI.EX. RANDALL, M.A., M.D. PHIIADELPHIA, PA.

Much work has been done in the last half century for the improvement of the hygiene of the school, with the result of formulating with much precision the best arrangement of the school building as regards site, plan, ventilation and illumination, and much of this is continually being put into practice with ever-growing advance in these matters of the school surroundings. The parallel and equally important field of educational methods has also been well worked by the pedagogues and others in response to the protest as to overburdened pupils; and while the standards of requirement have advanced and educational forcing has continued unabated, it is probable that the resulting damage has been materially lessened. More sweeping application of the rules generally accepted as requisite, is alone needful to place this aspect of the matter in fairly satisfactory shape.

Forced into rather wholesale dealing with their scholars by large clasees and the pressure of changing methods of instruction. the teachers as a class are yet sedulously careful of the health of their pupils and often nobly self-sacrificing in their efforts to ave them from any injury in the educational process. Were they enabled to make more discriminating application of preventive care to the cases requiring it, much more might be accomplished through the agencies already more or less practically in existence. The conditions surrounding the scholar have greatly improved; yet near-sight and many more certain evils have been little if at all decreased.

The difficulty is not so much with the machine methods as with the material submitted to them. The hygiene of the school may be perfect; yet that of the scholar very poor. Collective methods have their value-often great; but the application to individual cases may not only fail of good, but even be productive of much injury. Perfectly hygienic school surroundings with moderate demands upon the eves may save the majority of pupils from trouble, palliate the defective relations of others, and yet spread disaster among a notable minority. Very in. jurious home surroundings undermine the advantages of the most perfect sanitation in the school, and can be met only by personal examination of the scholars and the exclusion of the unfit from school tasks. Preventive measures can be only partially applied to the whole school population; while their application to the individuals most in need, will generally come only after some damage has become irretrievable, if 